\title{
REPORT
}

\section{A Report on the Fifteenth Conference of International Society for Ecological Economics}

\author{
Rajeswari S. Raina *
}

The $15^{\text {th }}$ Conference of the International Society for Ecological Economics (ISEE) on "Ecological Economics and Socio-ecological Movements: Science, Policy and Challenges to Global Processes in a Troubled World" turned out to be as intellectually engaging and academically challenging as the title promised. Following the revision of ISEE's mission statement ${ }^{1}$ in July 2017, this was the first ISEE conference that formally invited social movements and created a platform for academic and policy actors to dialogue with communities and movements. The interactions conclusively established the role and voice of communities and movements in understanding the interfaces between 'nature's household' (ecosystems) and 'humanity's household' (the economy). They highlighted the plurality of frameworks available to understand nature and society, and the economy as a significant sub-component of society.

The success of the conference, despite some inconvenience caused by the multiple venues across the captivating city centre of Puebla, was due to the perseverance of the organizers, David Barkin and Clovis Cavalcanti. They had to confront and overcome some serious financial and organizational hurdles in the build-up to the conference.

The conference had set out 12 major themes to address the challenges to global processes in our troubled world. Most importantly, it made a significant effort for cross-fertilization of ideologies, ideas, methods and

\footnotetext{
* Professor, School of Humanities and Social Sciences, Shiv Nadar University, NH91, Tehsil Dadri, Gautam Buddha Nagar, Greater Noida, Uttar Pradesh 201314; rajeswari.raina@snu.edu.in

Copyright (C) Raina 2019. Released under Creative Commons Attribution-NonCommercial 4.0 International licence (CC BY-NC 4.0) by the author.

Published by Indian Society for Ecological Economics (INSEE), c/o Institute of Economic Growth, University Enclave, North Campus, Delhi 110007.

ISSN: 2581-6152 (print); 2581-6101 (web).

DOI: https://doi.org/10.37773/ees.v2i1.67

1 http:/ / www.isecoeco.org/about/cross-discipline-approach/
} 
metrics of ecological economics, political ecology, ethnoecology, agroecology and energy systems. Some themes, academically more closely linked with ecological economics, like ecosystem services, valuation languages, tools of measurement and policy instruments, legal and social processes, multi-criteria analysis (theme 9), food security/sovereignty, and rural-urban transitions (theme 4), globally diverse inequities, social and environmental conflicts, environmental and climate justice, and ecological debt (theme 6), trans-disciplinary responses to socio-ecological contexts (theme 1), and energy transitions, climate analysis and policies (theme 10) were well represented. But the fate of several other themes central to the conference call for cross-fertilization of ideas and learning from and with communities was not the same. Though, the parallel sessions on some of these themes like social metabolism - evolving relationships between society and the planet (theme 5), and ecological macroeconomics: prosperity without growth (theme 7) did witness cross-fertilization between the usual silos of academic expertise and field-based community knowledge systems. A key debate in theme 5, was about the real biophysical and economic meanings of work and livelihoods that coevolve with ecosystems. Another debate in theme 7 was about the meanings and measures of 'good life', the nature of the state and regulatory authorities as well as legal institutions in contexts where economic growth for development is still sacrosanct across diverse political ideologies.

For many of us from INSEE and the global South, the three highlights of the conference were:

1. The first plenary session featuring community voices, indigenous concerns and solutions, which powerfully and convincingly articulated the need for ecological economics to work with and learn from communities;

2. A session of discussion on books, one featuring celebrated ecological economists on "TEEB (The Economics of Ecosystems and Biodiversity) for agriculture and food", and two new books on "Postgrowth thinking in India" and "De la protesta a la propuesta", where it became obvious that ecological economics would be forced to confront some tough choices in the coming decade;

3. The Kenneth Boulding prize award speech by Inge Roepke, recalling Boulding's spaceship earth which appeared in the 1960s, and asking the ecological economics community to be more creative, producing more transformative thought pieces (and not incremental square knowledge pegs for diversely shaped holes). 
Tying neatly and firmly into the theme of the conference, these three highlights underscore the demand for ecological economics to work more on 'how we know'. These highlights also bring us this larger concern about policies and practices within ecological economics. If the discipline is to contribute to sustainability, it needs to create more institutions and experiments designed for empirical adequacy and learning capacities in communities (in the fields, labs and administrative structures), and not just work towards universal generalizations and publications for citations.

The agenda to discuss 'science' and the scientific basis of many methods and measures, and actors (experts and policymakers), we consider critical for decision-making, was the least manifest in the conference. Perhaps this reflects the fate of ecological economics, which unquestioningly accepts scientific facts. At the conference, some questions about the legitimacy of currently institutionalized frameworks of science-policy relationships, and what qualifies in the mainstream as expertise or scientific disciplinary authority with social approval, were left unanswered. This lacuna continues to gnaw at the very core of ecological economics, despite the conference call that had specifically mentioned science as a global process to address our troubled world.

The key takeaway of this conference was that ecological economics, an inter-disciplinary knowledge formation integrating ecological sciences with values, behaviours, cultural practices, institutions, and social dynamics, has not, thus far, made attempts to engage with the multiple actors and in diverse forms of knowledge. Be it the processes of valuation of ecosystems, pricing mechanisms, or production policies, the ways in which scientific evidence 'speaks truth to power', the social construction of technology and science, or the coevolution of community-led local knowledge systems, ecological economics has the mandate to address the contents of and interactions between knowledge forms in ecosystems, societies and economies. Today, when the question about 'how we know what we know,' is being asked by all nine environmental social sciences (ranging from environmental history and cultural ecology to political ecology), this conference made it obvious that ecological economics has to step up and face this question as a global challenge.

That ecological economics and the other environmental social sciences need a different grammar to engage with community-based knowledge was evident in the discussions (in themes 2,7 and 12). There are opportunities offered by many socio-ecological movements like La Via Campesina or the Solidarity Economy. The alternative macroeconomics, political and institutional/legal concepts in these movements are forms of knowledge, integrated across knowledge-policy-practice continuums. These, therefore, 
make it important for ecological economics to engage with the critical voice of science and its ability to constantly renew itself, enliven disciplines and engage meaningfully with several other knowledge systems. But this, and the capacity of socio-ecological movements and the environmental social sciences to create the opportunity for diverse forms of knowledge to renew themselves, and change meanings and practices in daily life, may have to wait till the next Conference of the ISEE! 